\title{
Nutritional Composition of Some Leafy Vegetables Consumed in Imo State, Nigeria
}

\author{
*IHEANACHO, KIZITO M.E.; ${ }^{2}$ UDEBUANI, ANGELA C. \\ *Department of Biochemistry, Federal University of Technology, Owerri, P.M.B. 1526, Owerri, Imo State, Nigeria. 08033311720. \\ iheanachokizito@gmail.com \\ ${ }^{2}$ Department of Biotechnology, Federal University of Technology, Owerri. P.M.B 1526, Owerri, Imo State, Nigeria.
}

\begin{abstract}
Leafy vegetables are source of macro and micronutrients that play major role in maintaining healthy living. The chemical composition of undefatted and defatted vegetables; Amaranthus hybridus, Curcubita pepo and Gnetum africana was analyzed using the methods of Association of Analytical Chemist (AOAC) 1990. The moisture content of undefatted A.hybridus, C.pepo and G. africana was $8.35 \% \pm 0.05$, $8.55 \% \pm 0.01$ and $7.60 \% \pm 0.01$ respectively while defatted samples had $17.60 \% \pm 0.01,18.70 \% \pm 0.02$ and $15.00 \% \pm 0.01$ respectively. Undefatted A.hybridus, C.pepo and G. africana had $1.60 \% \pm 0.02,4.15 \% \pm 0.02$ and $7.10 \% \pm 0.02$ of crude lipids respectively. The crude protein content of defatted A.hybridus, C.pepo and G. africana was $12.04 \% \pm 0.00,21.60 \% \pm 0.01$ and $4.86 \% \pm 0.01$ respectively while undefatted A.hybridus, C.pepo and $G$. africana had crude protein of $32.95 \% \pm 0.01,20.80 \% \pm 0.02$ and $19.67 \% \pm 0.01$ respectively. The crude fibre content of undefatted A.hybridus, C.pepo and G. africana was $19.60 \% \pm 0.01,16.35 \% \pm 0.00$ and $27.25 \%$ \pm 0.00 respectively while defatted A.hybridus, C.pepo and G. africana had crude fibre content of $12.40 \% \pm$ $0.01,3.16 \% \pm 0.01$ and $13.70 \% \pm 0.00$ respectively. The ash content of undefatted A.hybridus, C.pepo and G. africana was $17.70 \% \pm 0.01,15.20 \% \pm 0.02$ and $8.00 \% \pm 0.02$ respectively while the ash content of defatted A.hybridus, C.pepo and G. africana was $43.60 \% \pm 0.02,43.60 \% \pm 0.02$ and $47.90 \% \pm 0.02$ respectively. The total carbohydrate content of undefatted A.hybridus, C.pepo and G. africana was $15.40 \% \pm 0.02,30.40 \% \pm 0.01$ and $30.38 \% \pm 0.01$ respectively while the total carbohydrate content of defatted A.hybridus, C.pepo and G. africana, was $14.36 \% \pm 0.01,12.94 \% \pm 0.01$ C.pepo and G. africana, was $14.36 \% \pm 0.01,12.94 \% \pm 0.01$ and $18.54 \% \pm 0.01$ respectively. The mineral composition of udefatted A.hybridus, C.pepo and G. africana showed $64.60 \mathrm{mg} / \mathrm{g}, 38.60 \mathrm{mg} / \mathrm{g}$ and $10.50 \mathrm{mg} / \mathrm{g}$ of sodium; $11.05 \mathrm{mg} / \mathrm{g}, 9.08 \mathrm{mg} / \mathrm{g}$ and $3.40 \mathrm{mg} / \mathrm{g}$ of potassium; $13.68 \mathrm{mg} / \mathrm{g}$, $11.52 \mathrm{mg} / \mathrm{g}$ and $3.60 \mathrm{mg} / \mathrm{g}$ of magnesium; $28.80 \mathrm{mg} / \mathrm{g}, 32.00 \mathrm{mg} / \mathrm{g}$ and $13.60 \mathrm{mg} / \mathrm{g}$ of calcuim; $87.50 \mathrm{mg} / \mathrm{g}, 65.25$ $\mathrm{mg} / \mathrm{g}$ and $78.75 \mathrm{mg} / \mathrm{g}$ of iron; $0.99 \mathrm{mg} / \mathrm{g} 1.15 \mathrm{mg} / \mathrm{g}$ and $0.35 \mathrm{mg} / \mathrm{g}$ of phosphorus respectively. Defatted A.hybridus, C.pepo and G. africana showed mineral composition of $24.80 \mathrm{mg} / \mathrm{g}, 17.50 \mathrm{mg} / \mathrm{g}$ and $6.14 \mathrm{mg} / \mathrm{g}$ of sodium; $8.65 \mathrm{mg} / \mathrm{g}, 4.64 \mathrm{mg} / \mathrm{g}$ and $4.10 \mathrm{mg} / \mathrm{g}$ of potassium; $12.48 \mathrm{mg} / \mathrm{g}, 2.18 \mathrm{mg} / \mathrm{g}$ and $3.36 \mathrm{mg} / \mathrm{g}$ of magnesium, $26.40 \mathrm{mg} / \mathrm{g}, 28.40 \mathrm{mg} / \mathrm{g}$ and $12.80 \mathrm{mg} / \mathrm{g}$ of calcium; $0.81 \mathrm{mg} / \mathrm{g}, 45.00 \mathrm{mg} / \mathrm{g}$ and $37.50 \mathrm{mg} / \mathrm{g}$ of iron; $8.57 \mathrm{mg} / \mathrm{g}$, $1.12 \mathrm{mg} / \mathrm{g}$ and $0.18 \mathrm{mg} / \mathrm{g}$ of phosphorus respectively. The cyanogenic glycoside was higher in the undefatted than the defatted vegetables. Based on the results obtained it is more rewarding nutritionally to consume leafy vegetables in their undefatted form. @ JASEM
\end{abstract}

Vegetables are the edible parts of plant that are consumed wholly or in parts, raw or cooked as part of main dish or salad. A vegetable includes leaves, stems, roots, flowers, seeds, fruits, bulbs, tubers and fungi (Uzo, 1989; Uwaegbute, 1989). The leafy vegetables investigated were Amaranthus hybridus commonly called African spinach, Curcubita pepo commonly called marrow and Gnetum africana which belong to the family of plants called Gnetaceae. The increasing population of many tropical countries led to awareness of the importance of vegetables as a source of essential nutrients which may not be available in other food sources. Vegetables are good sources of oil, carbohydrates, minerals and vitamins depending on the vegetable consumed (Ihekoronye and Ngoddy, 1985). Undefatted leafy vegetable is the vegetable that has its total crude lipid content not isolated while defatted leafy vegetable is the vegetable that has its total crude lipid content isolated. Undefatted leafy vegetables play the role of being a source of energy to man, lipids in the vegetable help in maintaining the integrity of the cell membrane, lipids in vegetables protects the body from mechanical injury when deposited in the adipose tissues and lipids in vegetables make it palatable for eating (Ononugbu,2002). Undefatted vegetable serves the function of transporting fat soluble vitamins (A,D,E and $\mathrm{K}$ ) and in combination with certain proteins called apoproteins mediate a number of enzyme activities (Ononugbu, 2002). Ononugbu, 2002 reported that vegetable fats and oils lower blood lipids thereby reducing the occurrence of disease associated with the damage of the coronary artery. Vegetable fats and oils serve as precursors of prostagladins which are known to perform the role of vasoconstriction and vasodilation of the blood vessels. Vegetable fats and oils are known to serve as precursors of thromboxane which facilitate blood clotting in humans (Ononogbu, 2002). In defatted leafy vegetables off-flavours and odorous state are eliminated and these are as a result of lipid autoxidation which eventually leads to rancidity.

Amaranthus hybridus is known to people from South Eastern Nigeria as 'inene' and it belongs to the family Amaranthacae. Amaranthus hybridus tolerates varing soil and climatic conditions but altitudes of over $1500 \mathrm{ft}$ are unsuitable (Tyndall, 1968). Amaranthus hybridus is widely grown in West Africa, Indonesia and Malaysia (Hugue, 1989). Amaranthus hybridus is an annual plant, it is spineless and up to $80 \mathrm{~m}$ high with grooves. The leaves are green and variable in shape and size.

Curcubita pepo is commonly called marrow. In South Eastern Nigeria, it is known as 'Ugbogulu'. It belongs to the family Curcubitacae. Curcubita pepo grows in Malaysia and tropics (Hugues, 1989). C.pepo is a dry season crop which is 
adversely affected by excessive humidity and high temperature (Tyndall, 1968). It is an annual plant. It has prickly stems and the leaves are large with rough surface. The male and female flowers are on the same plant. $C$. pepo fruits are variable in size, shape and colour (Tyndall, 1968). C. pepo plays important role as first-crop plants and functions as cover plants (Hugues et al, 1989). The major disease that affects C.pepo is the downy mildew and it is remedied by spraying or dusting with copper fungicide (Tyndall, 1968).

Gnetum africana belongs to the family of plants called Gnetaceae. In Nigeria it is known as 'Ukazi' or 'Afang'. Gnetum africana is classified as a glabrous woody climber with nodes, Orthortrophic vegetable branches with fibrous roots which adhere for support (Purseglove, 1981). Gnetum africana grows up to $7 \mathrm{~m}$ or more and bears fruits in the fifth year after planting. They are found in the humid areas and in the rain forest zones (Aguta, 1985). Okafor, (1983) reported that Gnetum africana which is collected from the forest may disappear in Nigeria if nothing is done to domesticate it. In Southern Nigeria Gnetum africana is used for preparation of soup and salad. The salad is often eaten as a mild laxative and its high fibre content helps to prevent constipation (Bako et al, 2002). As a potent medicinal plant it is used in the treatment of piles and high blood pressure (Okafor,1983). Bako et al, 2002 reported that the leaves cure stomach disorder and prevents constant urination in nursing mothers.

The objectives of this research is to evaluate the chemical constituents of undefatted and defatted Amaranthus hybridus, Curcubita pepo and Gnetum africana. Also ascertain if defatting affects the bioavailability of these chemical constituents in the leafy vegetables.

\section{MATERIALS AND METHODS Materials \\ Sample collection:}

Fresh samples of Amaranthus hybridus leaves, Curcubita pepo leaves and Gnetum africana were purchased from a local market in Owerri, Imo State Nigeria.

\section{Identification of Sample:}

The samples of Amaranthus hybridus, Curcubita pepo and Gnetum africana leaves were identified by Mr. E. Onuoha, of the Department of Crop Science, Federal University of Technology, Owerri, Imo State, Nigeria.

\section{Sample preparation:}

Amaranthus hybridus, Curcubita pepo and Gnetum africana leaves were thoroughly washed with clean tap water. These samples wee air-dried at room temperature and then oven dried at $60^{\circ} \mathrm{C}$. The leaves were later pulverized using mortar and pestle and were packed in polythene bags.

\section{Methods}

Determination of chemical constituent in the leafy vegetables:

Chemical analyses of the leaves of Amaranthus hybridus, Curcubita pepo and Gnetum africana were carried out to determine the protein, carbohydrate, lipid, fibre, ash and moisture content of each of them using Association of Analytical chemists (AOAC) method, 1990.

Determination of Minerals in the leafy vegetables. The flame photometric method was used in determining the sodium $(\mathrm{Na})$ and Potassium $(\mathrm{K})$ content. Spectrophotometric method was used in determining the phosphorus (P) and Iron (Fe) content while complexometric titration method was used in determining calcium $(\mathrm{Ca})$ and magnesium $(\mathrm{Mg})$ content of these three leafy vegetables (Association of Analytical Chemists, AOAC, 1990).

\section{RESULTS AND DISCUSSION}

The results of the chemical composition (Proximate analysis) and mineral composition of undefatted and defatted leaves of Amaranthus hybridus, Curcubita pepo and Gnetum africana are as shown below.

Table 1: Proximate analysis of the nutritional composition of undefatted leaves of Amaranthus hybridus, Curcubita pepo and Gnetum africana.

\begin{tabular}{llll}
\hline & A. hybridus & C. pepo & G.africana \\
Moisture (\%) & $8.35 \pm 0.05$ & $8.55 \pm 0.01$ & $7.60 \pm 0.01$ \\
Crude lipid (\%) & $1.60 \pm 0.02$ & $4.15 \pm 0.02$ & $7.10 \pm 0.02$ \\
Crude protein (\%) & $32.95 \pm 0.01$ & $20.80 \pm 0.02$ & $19.67 \pm 0.01$ \\
Crude fibre (\%) & $19.60 \pm 0.01$ & $16.35 \pm 0.00$ & $27.25 \pm 0.00$ \\
Ash (\%) & $17.70 \pm 0.01$ & $15.20 \pm 0.02$ & $8.00 \pm 0.02$ \\
Total carbohydrate (\%) & $15.40 \pm 0.02$ & $30.40 \pm 0.01$ & $30.38 \pm 0.01$ \\
\hline
\end{tabular}

Values are means of triplicate determination \pm S.E.M

Table 2: Proximate analysis of the nutritional composition of defatted leaves of Amaranthus hybridus, Curcubita pepo and Gnetum africana.

\begin{tabular}{llll}
\hline & A. hybridus & C. pepo & G.africana \\
Moisture (\%) & $17.60 \pm 0.01$ & $18.70 \pm 0.02$ & $15.00 \pm 0.01$ \\
Crude protein (\%) & $12.04 \pm 0.00$ & $21.60 \pm 0.01$ & $4.86 \pm 0.01$ \\
Crude fibre (\%) & $12.40 \pm 0.01$ & $3.16 \pm 0.01$ & $13.70 \pm 0.00$ \\
Ash (\%) & $43.60 \pm 0.02$ & $43.60 \pm 0.02$ & $47.90 \pm 0.02$ \\
Total carbohydrate (\%) & $14.36 \pm 0.01$ & $12.94 \pm 0.01$ & $18.54 \pm 0.01$ \\
\hline
\end{tabular}

Values are means of triplicate determination \pm S.E.M

Table 3: Mineral composition of undefatted leaves of Amaranthus hybridus, Curcubita pepo and Gnetum africana.

\begin{tabular}{llll}
\hline Mineral & \multicolumn{2}{l}{ Concentration $(\mathrm{Mg} / \mathrm{g})$} \\
& A. hybridus & C. pepo & G.africana \\
Sodium $(\mathrm{Na})$ & 64.60 & 38.60 & 10.50 \\
Potassium $(\mathrm{K})$ & 11.05 & 9.08 & 3.40 \\
Magnesium $(\mathrm{Mg})$ & 13.68 & 11.52 & 3.60 \\
Calcium $(\mathrm{Ca})$ & 28.80 & 32.00 & 13.60 \\
Iron $(\mathrm{Fe})$ & 87.50 & 65.25 & 78.75 \\
Phosphorus $(\mathrm{P})$ & 0.99 & 1.15 & 0.35 \\
\hline
\end{tabular}


Table 4: Mineral composition of defatted leaves of Amaranthus hybridus, Curcubita pepo and Gnetum africana.

\begin{tabular}{llll}
\hline Mineral & \multicolumn{3}{l}{ Concentration $(\mathrm{Mg} / \mathrm{g})$} \\
& A. hybridus & C. pepo & G.africana \\
Sodium $(\mathrm{Na})$ & 24.80 & 17.50 & 6.14 \\
Potassium $(\mathrm{K})$ & 8.65 & 4.64 & 4.10 \\
Calcium $(\mathrm{Ca})$ & 26.40 & 28.40 & 12.80 \\
Magnesium $(\mathrm{Mg})$ & 12.48 & 2.18 & 3.36 \\
Phosphorus $(\mathrm{P})$ & 8.57 & 1.12 & 0.18 \\
Iron $(\mathrm{Fe})$ & 0.81 & 45.00 & 37.50 \\
\hline
\end{tabular}

Table 5: Cyanogenic glycoside content of undefatted leaves of A. hybridus, C.pepo, and G. africana

Concentration of undefatted (Mg/100g)

Cyanogenic A.hybridus C.pepo G.africana glycoside

$2.16 \pm 0.01 \quad 2.59 \pm 0.00 \quad 1.73 \pm 0.01$

Values are means of triplicate determination \pm S.E.M

Table 6. Cyanogenic glycoside content of the undefatted leaves of A. hybridus, C.pepo, and G. africana

Concentration of defatted $(\mathrm{Mg} / 100 \mathrm{~g})$

$\begin{array}{llll}\text { Cyanogenic A. hybridus } & \text { C.pepo G.africana }\end{array}$ Glycoside

$1.72 \pm 0.01 \quad 2.16 \pm 0.00$

$1.29 \pm 0.02$

Values are means of triplicate determination \pm S.E.M

The undefatted A. hybridus, C.pepo had higher percentage of moisture when compared with G. africana. The high moisture content provides for greater activity of water soluble enzymes and coenzymes needed for metabolic activities of these leafy vegetables.

G. africana had $7.10 \pm 0.02 \%$ of crude lipid when compared with A. hybridus, C.pepo with 1.60 $\pm 0.02 \%$ and $4.15 \pm 0.02 \%$ respectively.

This shows that $G$. africana contains more lipid biomolecules than A. hybridus and C.pepo.

$A$ hybridus had $32.95 \pm 0.01 \%$ crude protein when compared with $20.80 \% \pm 0.02 \%$ and $19.67 \pm 0.01 \%$ of crude protein in G. africana and C. pepo. The high crude protein content in $A$. hybridus suggests its richness in essential amino acids. These amino acids serve as alternative source of energy when carbohydrate metabolism is impaired via gluconeogenesis.

G. africana had $27.25 \pm 0.00 \%$ of crude fibre when compared with A.hybridus and C. pepo with crude fibre values of $19.60 \pm 0.01 \%$ and $16.35 \pm 0.00 \%$. The high fibre content justifies the leathery nature of $G$. africana leaf and its use as a laxative when cooked and eaten in large amount during constipation (Bako et al, 2002).

The ash content of $A$. hybridus was $17.70 \pm 0.01 \%$ while $C$. pepo had $15.20 \pm 0.02 \%$ and G.africana had at least $8.00 \pm 0.02 \%$. This confirms that there are more minerals in $A$. hybridus and $C$. pepo than $G$. africana. These minerals act as inorganic cofactors in metabolic processes. In the absence of these inorganic cofactors there could be impaired metabolism. The total carbohydrate content was $30.40 \pm 0.01 \%$ in $C$. pepo, $30.38 \pm 0.01 \%$ in $G$. africana higher than $15.40 \pm 0.02 \%$ in A. hybridus. Carbohydrate metabolism is needed in the generation of reducing potentials required to carry out biosynthetic activities in the plant. The moisture content of $A$. hybridus, $C$. pepo and $G$. africana in a defatted form was far higher than the moisture content of undefatted A. hybridus, $C$. pepo and $G$. africana. The crude protein content of undefatted A. hybridus, $C$. pepo and G. africana was higher than the crude protein of defatted $A$. hybridus, C. pepo and G. africana. In the course of defatting these leafy vegetables, the non-polar amino acids that were constituents of the macromolecule protein may have been extracted thereby reducing the percentage of crude protein in these leafy vegetables. The crude fibre content of undefatted $A$. hybridus, $C$. pepo and $G$. africana.was higher than the crude fibre content of defatted A. hybridus, C. pepo and G. africana. The total carbohydrate content of undefatted $A$. hybridus, C. pepo and G. africana was higher than the total carbohydrate content of defatted $A$. hybridus, C. pepo and G. africana. The variations in composition of other chemical constituents ither in undefatted or defatted forms of these leafy vegetables suggests some correlation between the crude lipid and other chemical constituents in these leafy vegetables. There was not much variation in Sodium, potassium, magnesium, calcium, iron, and phosphorus content in both the undefatted and defatted forms of A. hybridus, C. pepo and $G$. africana. Though the concentration values of these minerals in both undefatted and defatted shows that the minerals are predominate in the undefatted form than the defatted form. The cyanogenic glycoside which is an anti-nutritional factor was more prevalent in the undefatted than the defatted forms of these leafy vegetables. The reduced level of the cyanogenic glycoside in the defatted vegetables could be there partial solubility in lipid. In conclusion, it is preferable to consume these leafy vegetables in the undefatted form, since the undefatted form retains a higher level of these chemical constituents than the defatted form.

Acknowledgement: I sincerely thank Mr. E.O. Onuoha, a technologist in the Department of Soil Science Technology, Federal University of Technology, Owerri who assisted in carrying out the analysis in his laboratory. Also, I thank Mr. Ephraim Nwadike of the University of Port Harcourt who did the type setting of this work.

\section{REFERENCES}

Aguta, B. C. (1985). Agriculture in Nigeria (unpublished)

AOAC (1990). Association of Official Analytical Chemists. Official Method of Analysis, 15th edition, Washington DC. 
Bako, S. P.; Luka, S. A.; Bealo, E. B.; Aula, J. (2002). Ethanobotany and Nutrient Content of Gnetum africana in Nigeria. SCITECH Publishers, USA. 79-84.

Hugues, D; Philip, D. L. (1989). African Garden and Orchards. Macmillian Publishers London. 30-35.

Ihekoronye, A. I.; Ngoddy, P. O. (1985). Tropical Fruits and Vegetables. In Integrated Food Science and Technology for the Tropics. Macmillian Publishers, London. 293-304.

Okafor, J. O. (1983). Horticultural Promising Indigenous Wild Plant Species of the Nigeria Forest Zone. Hort 123:165-176.
Ononogbu, I.C. (2002). Lipids in Human Existence. 1st edition. AP Express Publishing Company, Nsukka 1-15.

Purseglove, J. W. (1981). Leguminosae. In: Tropical Crops. Longman Group Ltd, Essex, UK. p15.

Tindall, H. D. (1983). Vegetables in the Tropics. 5 th edition. Macmillian publishers London. 1452.

Uwaegbute, A. C. (1989) Vegetables: Nutrition and Utilization. In: Food Crops Production. Dotan Publishers Ltd Ibadan. 39-44.

Uzo, J. O. (1989). Tropical Vegetable Production. In: Food Crops Production. Dotan Publishers Ltd Ibadan. 45-49. 